\title{
A practical way to integrate risk in forest management decisions
}

\author{
Torsten B. Möllmann ${ }^{1}$ • Bernhard Möhring ${ }^{1}$
}

Received: 21 April 2017 / Accepted: 23 October 2017 /Published online: 21 November 2017

(C) INRA and Springer-Verlag France SAS 2017

\begin{abstract}
- Key message The concept of expected losses is an appropriate measure for integrating risk in the determination of the optimal rotation period and choice of tree species.

- Context Natural threats are challenging forest management decisions. Essential decisions about the optimal length of a harvest period are often taken without considering risks.

- Aims Here, a practical and easy to apply way to integrate risk in these decisions is shown. Furthermore, it is seen how the rotation period changes according to the risk-type and risk-level. - Methods The marginal principle of Preßler's indicator rate is developed further by including the concept of expected losses, leading to an optimal harvest age under risk. The application of the new formula is shown by a simulation, which also visualises the influence on the optimal rotation age.

- Results Whether risk influences the optimal harvest age compared to a risk free solution, depends on the relationship between expected losses in terms of land rent of the succeeding stand and expected losses in terms of value growth of the existing stand. If they are equal, the rotation age stays. If the expected loss on value growth is bigger than on land rent,
\end{abstract}

Handling editor: Rasoul Yousefpour

Contribution of the co-authors Torsten B. Möllmann wrote the article under the supervision of Bernhard Möhring.

This article is part of the Topical Collection on Risk Analysis

Torsten B. Möllmann

tmoellm@gwdg.de

Bernhard Möhring

bmoehri@gwdg.de

1 Faculty of Forest Science, Forest Economics and Forest Management, Georg August-Universität Göttingen, Büsgenweg 3, 37077 Göttingen, Germany the rotation period will be shorter, while it will be longer if the relation is inverse.

- Conclusion The concept of expected losses can be applied to practically determine the optimal rotation period under risk.

Keywords Expected loss $\cdot$ Risk-costs $\cdot$ Forest management . Faustmann-Preßler-Ohlin-theorem · Optimal rotation ·

Harvest decision

\section{Introduction}

Forests are exposed to many kinds of threats. Storms, fires, and insect plagues can considerably change their characteristics and lead to economic losses. Hence, these disturbances have to be considered in management decisions - a procedure well developed in general business economics but scarcely in forestry (Hanewinkel et al. 2011). The long production cycles in forestry make it an especially challenging task. This counts even more, as a changing climate renders future developments hard to predict. At a minimum however, assumptions about probabilities and potential damage are needed for the application of risk-handling measures. If one of these factors is missing, the situation is uncertain (Klemperer 1996). This dependency on probabilities underlines the importance of studies that try to find out how growing conditions and risks might look in the future (Schelhaas et al. 2015; Kölling et al. 2016).

The aim of this study was to develop a concept to value natural risks, in order to consider them in management decisions based on survival probabilities, and to analyze their meaning for decisions. Considering a profit-maximizing forest owner, the concept of expected losses seems suitable. This concept calculates the expected value of an investment's loss by multiplying the probability of a possible loss by its loss amount (Campalongo et al. 2013). If the expected loss is 
subtracted from the risk-free outcome, the expected value of the investment is the result. In forestry, the risk-free outcome can be seen in production models ignoring natural hazards. Considering the forester as risk-neutral, the expected value of an investment can be seen as decision value, as riskneutral decision makers neither positively nor negatively value the variance of the results (Abdellaoui et al. 2011). The use of expected losses might help to clarify how much, on average, natural threats cost forest enterprises. Therefore, the term risk-costs could also be used to underline that natural threats can and should be considered in cost accounting.

Although this concept is rather intuitive, it is, to our knowledge, not yet established in forestry. However, it has been used to calculate the net insurance premium for forest insurances (Holthausen et al. 2004; Holecy and Hanewinkel 2006; Brunette et al. 2015). Haight et al. (1995) showed how to calculate a stand's expected present value and compare it to the risk-free context. However, he focused on single rotations and did not work out how expected losses can be used as steering parameters.

Following these thoughts, the first hypothesis can be formulated as: the concept of expected losses is a reasonable concept to value natural risk in forestry.

In regard to risk-dependent decisions, it can be stated that the two major decisions in forestry are what to plant and when to harvest. A profit-maximizing forester would generally choose the most profitable species. Since the profitability of a species depends on the chosen rotation period, these two decisions are interlinked. Therefore, this study addresses the influence of risk on the harvest decision, leading to the second hypothesis: considering expected losses will lead to an adjustment of the optimal harvest age.

The two hypothesis will be tested by theoretical reflections on the harvest decision and illustrated by simulations. Before simulating, it was necessary to gather empirical data to estimate loss amounts, since no suitable data was found in literature. Therefore, material and methods as well as results are split into two parts: the first will show how empirical data was gathered and present the results. A second part will test the hypothesis.

\section{Quantifying loss amounts}

\subsection{Materials and methods to quantify loss amounts}

An online survey was conducted in Germany in autumn 2015. The aim was to generate data on loss amounts throughout the country. It was seen as an appropriate method to generate data beyond the scope of a local case study. The participating forest owners and forest managers were recruited via professional foresters' organisations and organisations of forest owners. The objective was to obtain responses from all parts of Germany, representing different types of site conditions, terrain, customers, etc.

The reasoning behind the survey was that both prices and cost changes depend on many variables. Modelling average conditions is complex, and sources are not available for all parameters. When forests are hit by a damaging event, forest management is affected in multiple ways. Timber prices might be affected directly: the incident will lower quality through breaking, twisting, etc. These effects are difficult to model. To work out price reductions due to a decline in quality, shifts in assortments, diameter distribution, etc. need to be known. But all this does not cover contract-of-sales-clauses regulating that a lower price is paid for calamity wood. Besides direct consequences, changes in the market might occur when markets are flooded with timber. Yet, many events are local, and bigger events do not necessarily lead to changes in the market.

Another direct result is that of changing costs for harvesting. Here, many factors come together, and the effects can be contradictory. If a stand has been blown down, a harvester might work more efficiently than in selective logging. On the contrary, the driver might have to replace the saw chain more often. In addition, the proportion of wood volume harvested manually changes with regards to the volume harvested mechanically, as does the share of the volume harvested by in-house workers and contractors. Depending on the tariff, the payment mode might also shift from a volume-based payment to a time wage. All these effects should be considered.

The participants were asked to estimate how harvest costs and wood prices change in salvage loggings due to storm, fire and insect damage. The aim in defining the parameters was to be specific enough so that the foresters were able to answer, but also general enough to provide mean values. According to individual experiences, questions were either about broadleaved trees or conifers. In the case of broadleaved trees, questions focused only on storm damage, since other damage occurs so seldom that it was questionable whether there was enough experience.

Regarding wood prices, it was stated that the wood market was not affected. Price changes should only concern a reduction in quality. Harvest costs were split into large and small areas to cope with different shares of transportation costs for machines and workers. The term "small area" means that only a few trees are affected (sanitary felling), while "large area" indicates damage to at least the compartment.

\subsection{Resulting loss amounts}

A total of 142 participants gave their estimation of the influence of hazards on prices and harvest costs in the online survey. According to the participants' characteristics, the results are based on highly educated foresters, predominantly in management positions, representing a wide variety of forest areas in Germany. Most of the participants work for or own private forest enterprises $(56 \%$ ), while $22 \%$ work for state and $8 \%$ for 
Table 1 Characteristics describing the surveyed foresters

\begin{tabular}{lll}
\hline Participants' characteristics & Mean & Standard deviation \\
\hline Female participants (\%), binary coded & 11.2 & - \\
Participants age (years) & 52.2 & 14.9 \\
Educational years (years) & 16.3 & 2.8 \\
Size of forest land (ha) & 9715 & 43,426 \\
Share of forest fire wood in sales volume of last 10 years (\%) & 0.4 & 1.5 \\
Share of wind-throw wood in sales volume of last 10 years $(\%)$ & 14.8 & 15.1 \\
\hline
\end{tabular}

municipal forest offices. The rest work either as contractors or answered without specifying their occupation. Further characteristics are listed in (Table 1).

Participants had only to answer for either broadleaved trees or conifers. Therefore it should be noticed that the cost changes after storm calamities are comparable (Table 2). Value changes are only due to a decline in quality, without changes in the wood market.

\section{Hypothesis testing}

\subsection{Materials and methods to test the hypothesis}

\subsubsection{Expending the Faustmann-Preßler-Ohlin-theorem to risk}

As the aim of the study was to include risk in the harvest decision, it is worth considering how to determine the economically optimal harvest age in a risk-free context. Basically, one can distinguish between two different situations: either before or after a forest is established. The first case is called a decision of the optimal rotation period. This approach goes along with determining the optimal economic life time of, for example, technical investment goods such as machines by maximizing the annuity (Möhring 2009). In forestry, this value is often calculated by the use of the Faustmann formula
(Faustmann 1849) determining the maximum land expectation value.

However, foresters are seldom in the situation of afforesting bare land. Furthermore, under European conditions, forests need decades to mature. Meanwhile, essential conditions change. New wooden products lead to new price ratios, harvest techniques become more sophisticated, etc. So cases in which harvest decisions are taken after investing are much more common. This decision goes along with the calculation of optimal replacement time (Möhring 2009). Foresters usually talk about the final felling, or final harvest decision, to differentiate it from the optimal rotation period. This thought is already to be found in Preßler's indicator rate (Preßler 1860). Despite their conceptual differences, the optimal rotation period calculated via the Faustmann formula, and the final harvest decision determined by the marginal analysis of Preßler, will lead to the same result (Chang and Deegen 2011).

The indicator rate of Preßler $i r^{*}$ relates the annual value growth of an existing stand $V^{\prime}$ reduced by the annual land rent $l r$ of a successor stand to the stumpage value $V$ of the existing stand.

$i r^{*}=\frac{V^{\prime}-l r}{V}$

The land rent in this study is defined as annuity, which turns unsteady payments generated during the stand's life into a continuous annual stream. Calculated as gross margin, it

Table 2 Changes in wood prices and harvest costs after calamities. Values generated in an online survey of 142 professional foresters and forest owners

\begin{tabular}{lllllllll}
\hline Category of trees & Type of value & Fire price & $\begin{array}{l}\text { Fire costs } \\
\text { small area }\end{array}$ & $\begin{array}{l}\text { Fire costs } \\
\text { large area }\end{array}$ & Storm price & $\begin{array}{l}\text { Storm costs } \\
\text { small area }\end{array}$ & $\begin{array}{l}\text { Storm costs } \\
\text { large area }\end{array}$ & $\begin{array}{c}\text { Insect price } \\
\text { Conifers }\end{array}$ \\
& Median & $-50 \%$ & $+20 \%$ & $+10 \%$ & $-10 \%$ & $+20 \%$ & $+10 \%$ & $-20 \%$ \\
& Mean & $-44.1 \%$ & $+17.3 \%$ & $+8.6 \%$ & $-15.2 \%$ & $+20.9 \%$ & $+9.5 \%$ & $-22.4 \%$ \\
& SD & 29.8 & 15.9 & 15.8 & 12.8 & 15.2 & 17.0 & 18.6 \\
Broadleaved & Median & - & - & - & $-20 \%$ & $+20 \%$ & $+10 \%$ & - \\
& Mean & - & - & - & $-21.3 \%$ & $+23.7 \%$ & $+11.9 \%$ & - \\
& SD & - & - & - & 16.3 & 15.7 & 21.4 & - \\
\hline
\end{tabular}


contains only expenditures and revenues of forest works (planting, harvest, etc.). Administration and other fixed costs are not considered to focus on the parameters determining the solution of optimal harvest age (Johansson and Löfgren 1985). It is calculated by the pre-defined target rate $i r$.

According to Johansson and Löfgren (1985), a forest stand should be kept as long as $i r^{*}>i r$. When it is equal, one should harvest. As they explain, the solution for the optimal rotation age is only valid under the following assumptions:

1. The capital market is perfect. Any amount of money can be lent and borrowed at the same known interest rate.

2. All future timber prices and costs are known and constant.

3. Future timber yields are known.

As a forest stand should be harvested when $i r^{*}=i r$, the indicator rate can be replaced by the target rate, and the formula can be solved for $V^{\prime}$ in that it matches the Faustmann-Preßler-Ohlin-Theorem (FPOT) (Johansson and Löfgren 1985): a forest should be kept when its marginal productivity is higher than the opportunity costs (OC), which consist of the scarcity of capital and land, expressed by the interest yield of the bound capital and the gross land rent.

$V^{\prime}=V^{*} i r+l r$

So far, the FPOT excludes the existence of risk. Even more, the second assumption requires known and constant prices and costs, and the third assumption requires known timber yields. Yet, it is a core characteristic of risk that knowledge about these variables is limited. However, there might be estimates or empirical values available about yields, prices, and costs in cases of calamities. If, in addition, there is knowledge about probabilities for hazards, expected values $\hat{E}$ can be calculated. Value growth $V^{\prime}$ and land rent $l r$ include future developments, and thus the chance of calamities. In contrast, the bound capital $V$, which could be yielded at the moment of decision, can be seen as non-stochastic. So, the FPOT can be further developed to:

$\hat{E}\left[V_{c}^{\prime}\right]=V^{*} i r+\hat{E}\left[l r_{c}\right]$

Thereby, the index $c$ indicates the devaluating influence of risk. The difference between a risk-free outcome of an investment and its expected value under risk is generally known as expected loss (EL). It can also be calculated by summing up the product of loss amounts and the corresponding probabilities, leading to the following formula:

$V^{\prime}-E L\left[V_{c}^{\prime}\right]=V^{*} i r+l r-E L\left[l r_{c}\right]$
The term $E L\left[V_{c}^{\prime}\right]$ describes the EL in terms of value growth of the existing stand, which we also call current risk-costs, and $E L\left[l r_{c}\right]$ stands for the EL of the future stand in terms of land rent, which we also call average risk-costs.

\subsubsection{Simulation of expected losses}

3.1.2.1 Derivation of probabilities for calamities Hazard probabilities can be taken from survival functions, commonly used in forestry (Kouba 2002; Staupendahl and Möhring 2011; Neuner et al. 2015). Staupendahl and Möhring (2011) describe the survival function as the "probability that a given stand at a specific site reaches or even exceeds a specific age", or alternatively as "the share of the afforested area that, on average, is still present at a specific age". As their study shows, these probabilities can adequately be expressed by a Weibull-function. To be intuitively interpretable, they express the survival probability $S$ characterised by two parameters. The first, $S_{100}$, shows the probability of a stand living until the age of 100 . It can be understood as a description of the risk's severity and will be referred to as risklevel. The second is $\alpha$, describing the shape of the curve and, by this, the type of risk. If $\alpha$ equals one, the risk is indifferent to the stand's age. If it is smaller, juvenile risks are dominant. If it is bigger, old-age risks are most probable (Staupendahl 2011). The survival probability proceeds as expressed by the following equation, according to Staupendahl and Möhring (2011):

$S=S_{100}\left(\frac{t}{100}\right)^{a}$

The probabilities given by a survival function can be used to draw other probabilities necessary to calculate expected losses. The probability of a calamity occurring at a certain age-class is defined, for the application of discrete time, as the probability density function (Staupendahl and Möhring 2011):

$f=S_{t}-S_{t+1}$

The second derived probability is the hazard rate $h$. It describes the conditional probability of a stand dropping out in the next time frame. It can also be understood as the area share of age-class $t$ that will drop out in the next period (Staupendahl and Möhring 2011):

$h=\frac{f_{t+1}}{S_{t}}$

Thereby, the values of $f$ and $h$ depend on the time span covered by the chosen age-class.

The use of the survival function underlies specific assumptions: the object is a stand spreading over the smallest possible unit, the area covered by the crown of a mature tree. Every 
5 years, this stand is either untouched or completely affected by a calamity. After a damaging event, the stand has to be re-established. Gap openings are not conquered by neighbouring stands. Likewise, the damage of a neighbouring stand does not influence the stand's growing conditions or its stability.

\subsubsection{Scheme of the discrete calculation of expected losses} Expected loss in terms of value growth to calculate $E L\left[V_{c}^{\prime}\right]$ the loss amount and the corresponding probabilities must be known. The loss amount can be calculated as the difference between the sound $V^{\prime}$ and the calamity influenced value growth $V_{c}^{\prime}$, while the probability of a hazard occurring can be taken from Eq. (7).

$E L\left[V_{c}^{\prime}\right]=h *\left(V^{\prime}-V_{c}^{\prime}\right)$

Expected loss in terms of land rent while the previous calculation is intuitively understood, the calculation of $E L\left[l r_{c}\right]$ is a bit more challenging. The following explanation is based on two studies. Staupendahl and Möhring (2011) showed how to calculate $\hat{E}\left[l r_{c}\right]$. Burkhardt et al. (2014) proved it mathematically.

$\hat{E}\left[l r_{c}\right]$ needs to include all possible events that might occur between planting and the preset rotation age, together with the corresponding probabilities. Possible events are sound growth until the planned rotation age, and sound growth until a calamity-induced final harvest at the planned rotation age or younger.

The probability of a stand being harvested regularly at the foreseen rotation age can be directly taken from the survival function $S$, while the probability for a calamity induced harvest at a certain age has to be taken from the density function $f$. The calamity-induced harvest determines the length of a stochastic production period.

$\hat{E}\left[l r_{c}\right]$ is then calculated as mean annuity. As each annuity covers a different time-span according to the stochastic production period, it is not sufficient to average only by the probability of the occurrence of that stochastic production period. The average needs to be weighted by the length of the stochastic production period. Each production-length-weighted probability then must be multiplied by the respective annuity.

The following equation, adapted from Staupendahl and Möhring (2011), shows the calculation.

$\hat{E}\left[l r_{c}\right]=\frac{S_{r} * r * l r+\sum_{t=1}^{r} f_{t} * t * l r_{t, c}}{S_{r} * r+\sum_{t=1}^{r} f_{t}^{*} t}$

Thereby, the index $r$ denotes the regular rotation age, while $t$ stands for the possible ages in which calamities might occur, with $0<t \leq r$. The expected loss in terms of land rent can now be calculated as the difference between the risk free land rent and the expected:

$E L\left[l r_{c}\right]=\operatorname{lr}-\hat{E}\left[l r_{c}\right]$

3.1.2.3 Data base of the simulation The simulation is based on a German model of Norway spruce (Picea abies L.) on better sites (top height $36 \mathrm{~m}$ ). Growth functions were drawn from the decision support system "WaldPlaner" (Nagel 2010). The simulation is conducted by an elementary spreadsheet calculation using age-classes of 5 years. Possible events are planting, precommercial and commercial thinnings, regular final harvest, and calamity-induced final harvests. Prices and costs are taken from $\mathrm{H}$. von Bodelschwingh (unpublished, Projekt Umsetzung des Konzeptes der "Ökonomie der Ökosystemdienstleistungen" im Rahmen der Forsteinrichtung im Landesbetrieb HessenForst), describing the conditions in the State Forest of Hesse in the years 2010-2015.

In regard to the survival probability, the available survival functions of different tree species in Germany show a tendency to old-age risks $(\alpha>1)$ and to a risk-level of $S_{100}>0.7$ (Neuner et al. 2015; Griess et al. 2012; Staupendahl 2011; Staupendahl and Zucchini 2011). Yet, altering values were chosen to show the influence of the parameters. Risk-type $\alpha$ holds values of 0.5 (juvenile risk), 1.0 (age independent risk) and 3.0 (old-age risk). For a better visualisation of the effects, the risk-level has been set to $S_{100}=0.5$, representing high-risk sites of spruce in Germany (Staupendahl and Zucchini 2011). To describe the influence on EL $\left[r_{\mathrm{c}}\right]$ by risk-type and risklevel, simulations have also been carried out for $S_{100}$-values between 0.1 and 1.0. Furthermore, a stochastic sequence of stands has been modeled to produce exemplary graphs.

As the survival functions do not differentiate between the causes of the diebacks, it is not possible to properly allocate costs and price changes of different agents. Therefore, prices have been lowered by $15 \%$ and costs have been raised by $15 \%$ in the case of a calamity. These values correspond with the results of the survey, excluding the unlikely case of forest fires in spruce stands. To consider costs that are not covered by price and cost changes, additional costs of EUR 500 per affected hectare were added. These correspond with current market prices for plantation site preparation. The interest rate is set to $1.5 \%$, which is in the range of interest rates generally accepted as adequate for forestry in Germany (Griess and Knoke 2013; Holecy and Hanewinkel 2006).

\subsection{Results referring to the hypotheses}

\subsubsection{Theoretical deductions}

The FPOT is a measure used to obtain optimal harvest age, so the influence of EL on FPOT can be taken from Eq. (4). 
Fig. 1 This graph shows all possible annuities for a spruce stand scenario if the rotation age is set to 100 years and the model contains 5-year age-classes

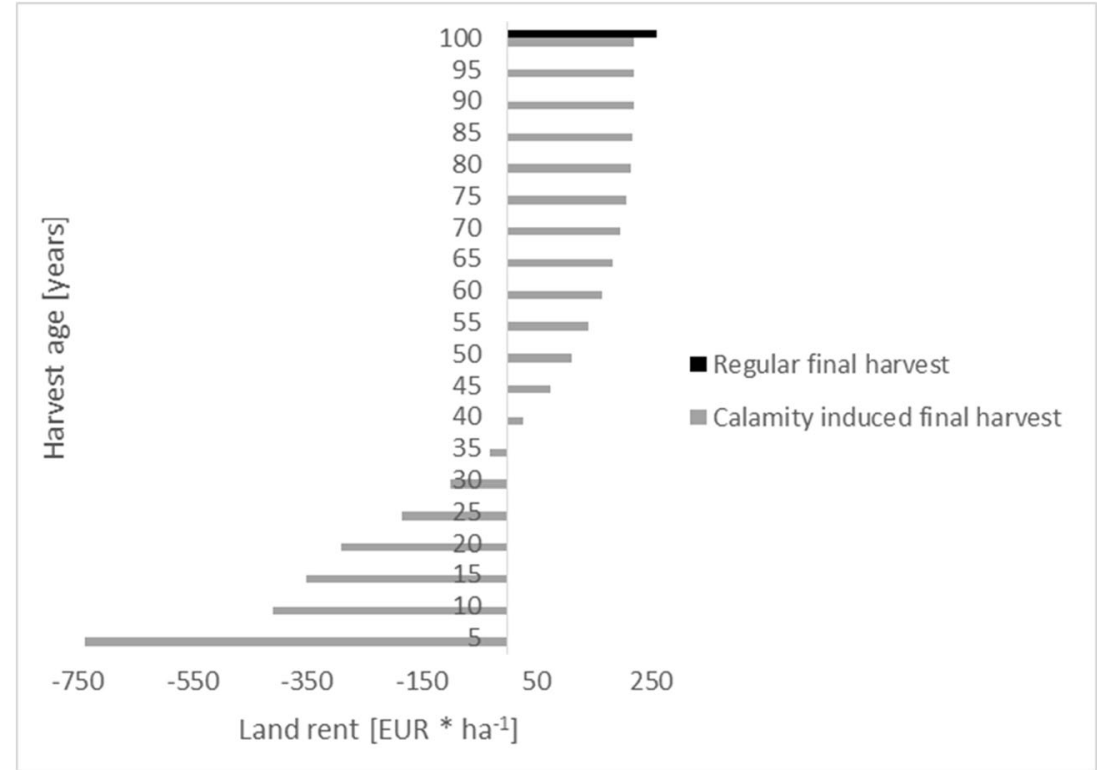

$V^{\prime}-E L\left[V_{c}^{\prime}\right]=V^{*} i r+l r-E L\left[l r_{c}\right]$

The relation between $E L\left[V_{c}^{\prime}\right]$ and EL $\left[r_{\mathrm{c}}\right]$ is essential. If they are equal, they can be cancelled and the risk-free solution for the optimal harvest will stay. In the case of inequality the optimal harvest age will change. If $E L\left[V_{c}^{\prime}\right]>E L\left[l r_{c}\right]$ the term left of the equal sign would be smaller than the one on the right side. To solve this inequality, the $\mathrm{OC}$ described in the right term needs to be lowered. This can be done by reducing the harvest age. The resulting risk-influenced optimal rotation period is shorter than the one of the risk-free solution. Thereby, it has to be considered that all variables of the equation are age-dependent. As $V^{\prime}$ is higher at a younger age, while $E L\left[V_{c}^{\prime}\right]$ is smaller, the resulting
Fig. 2 Probabilities representing the share of time that a rotation period holds in an eternal time sequence in high-risk spruce stands with old-age risks $\left(S_{100}=\right.$ 0.5 and $\alpha=3.0$ ). It can be seen that the chance for a land rent corresponding to the revenues of a regular final harvest at age 100 is $>50 \%$ due to the influence of the covered time span

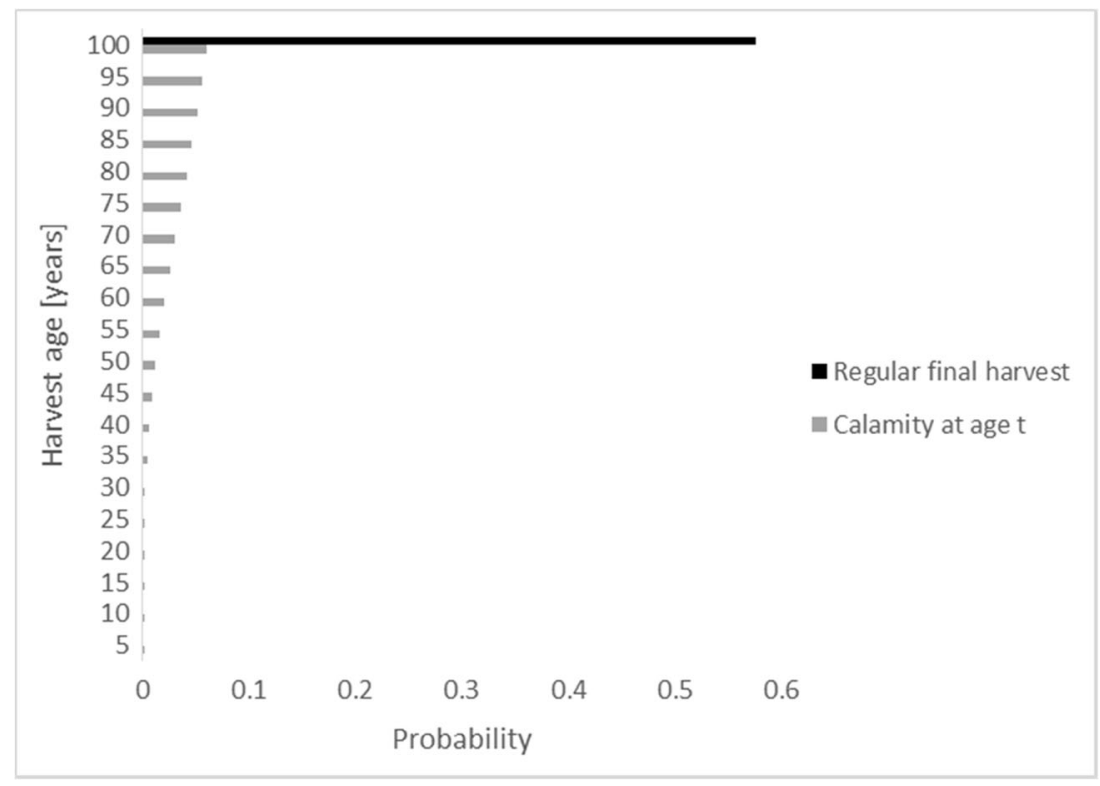




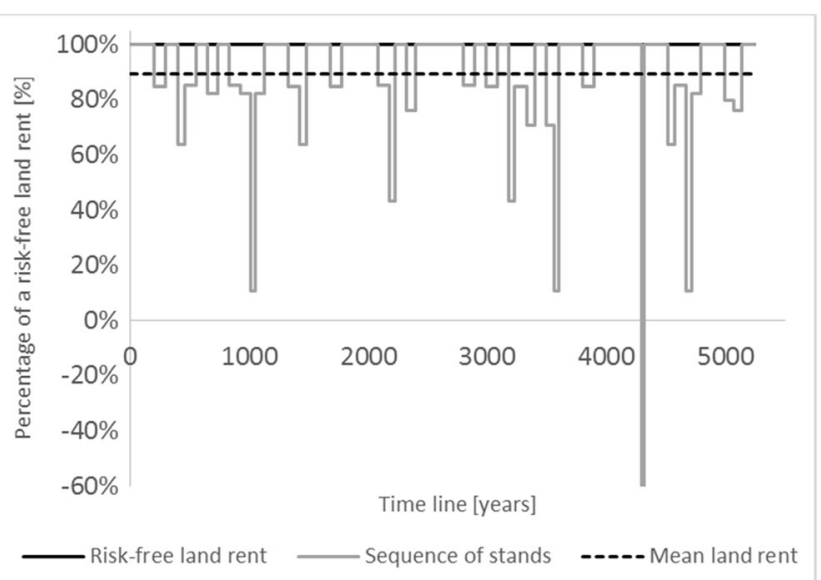

Fig. 3 Exemplary, arbitrary realisation of a stochastic sequence of spruce stands being either harvested regularly at age 100 or calamity induced. Calamity-induced harvests can happen earlier or at age 100. The survival function is defined by $S_{100}=0.5$ (high risk) and $\alpha=3.0$ (old-age risk). The regular land rent is set to $100 \%$, while it is lower in cases of calamityinduced final harvests. Furthermore, they last for a shorter time. The expected value, calculated as mean value, is determined by the survival probability at the end of rotation, the hazard probability density, the time span between planting and the final harvest, and the respective land rents

risk-inclusive optimum will lead to a higher $\hat{E}\left[l r_{c}\right]$ than the risk-free optimum. In the case of $E L\left[V_{c}^{\prime}\right]<E L\left[l r_{c}\right]$ the effect on the optimal rotation age is inverse. Originating ceteris paribus from the final felling solution of the risk-free context, the following can be understood:

1. With $E L\left[V_{c}^{\prime}\right]$ of the actual stand and EL $\left[l r_{\mathrm{c}}\right]$ of the replacement being either absent or equal, the time point of final felling remains.
2. If $E L\left[V_{c}^{\prime}\right]$ is bigger than the EL[ $\left[r_{\mathrm{c}}\right]$, the new harvest optimum will be at a younger age.

3. If $E L\left[V_{c}^{\prime}\right]$ is smaller than EL $\left[l r_{c}\right]$, the new harvest optimum will be at an older age.

Accordingly, EL can be used as a steering parameter. It confirms the implied behaviour of a forester, who presumably would harvest an existing stand earlier if the current risk is greater than the average risk of a replacement. Concerned stands are, for example, mature spruce stands, which are increasingly prone to storms. Vice versa, if the risk of replacement is greater than the current one, one should delay harvest. This might be the case for sites where it is extremely difficult to install the succeeding stand. By this, the sensitive phases during the rotation are reduced.

The proposed marginal principle of the FPOT deploys an advantage for non-equal replacements, when $l r$ follows a different production model than $V^{\prime}$. This might especially be relevant in regard to climate change. Given that the current stand will be replaced with the same species, it is to be expected that survival-risk will change. As climate change progresses slowly, one can assume that the conditions for a present mature stand can be modeled with empirical data. The survival conditions of the replacement, however, can be calculated according to climate predictions. This counts especially for old-age risks, which will be relevant in the mature phase. $E L\left[V_{c}^{\prime}\right]$ will stay, in contrast to $\operatorname{EL}\left[l r_{c}\right]$. Assuming that risk will increase due to a higher storm risk, more droughts, and more insect plagues, risk-type and risk-level will shift. If the future $S_{100}$-value is lower, the OC of the present stand will be lower than under the actual conditions. According to the risk-
Fig. 4 Graph showing risk-free land rents $l r$ for spruce as a function of preset rotation ages, risk-including expected values $\hat{E}$ for high old-age risks and the corresponding expected loss (EL)

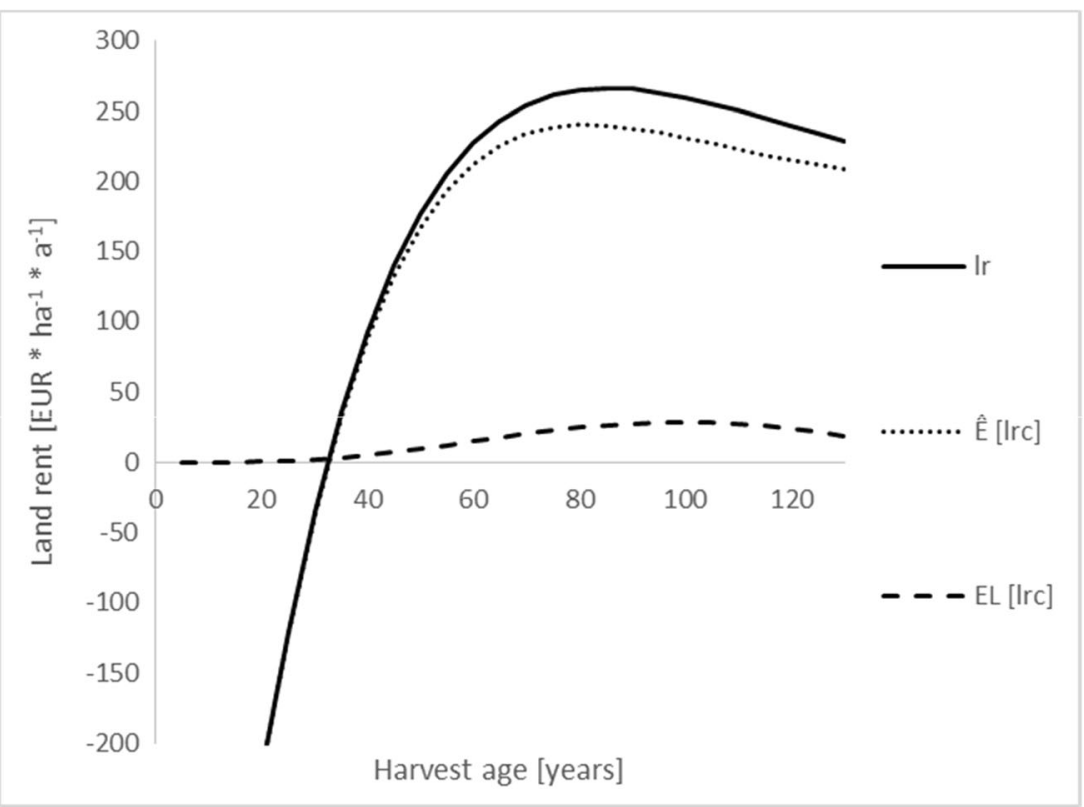


Fig. 5 Proceedings of value growth $\left(V^{\prime}\right)$ and opportunity costs (OC), their expected values $\hat{E}$ and the resulting EL of high-risk spruce stands $\left(S_{100}=0.5\right)$ under age-indifferent risk $(\alpha=1.0)$. If EL values are equal, optimal harvest is carried out as in a riskfree scenario

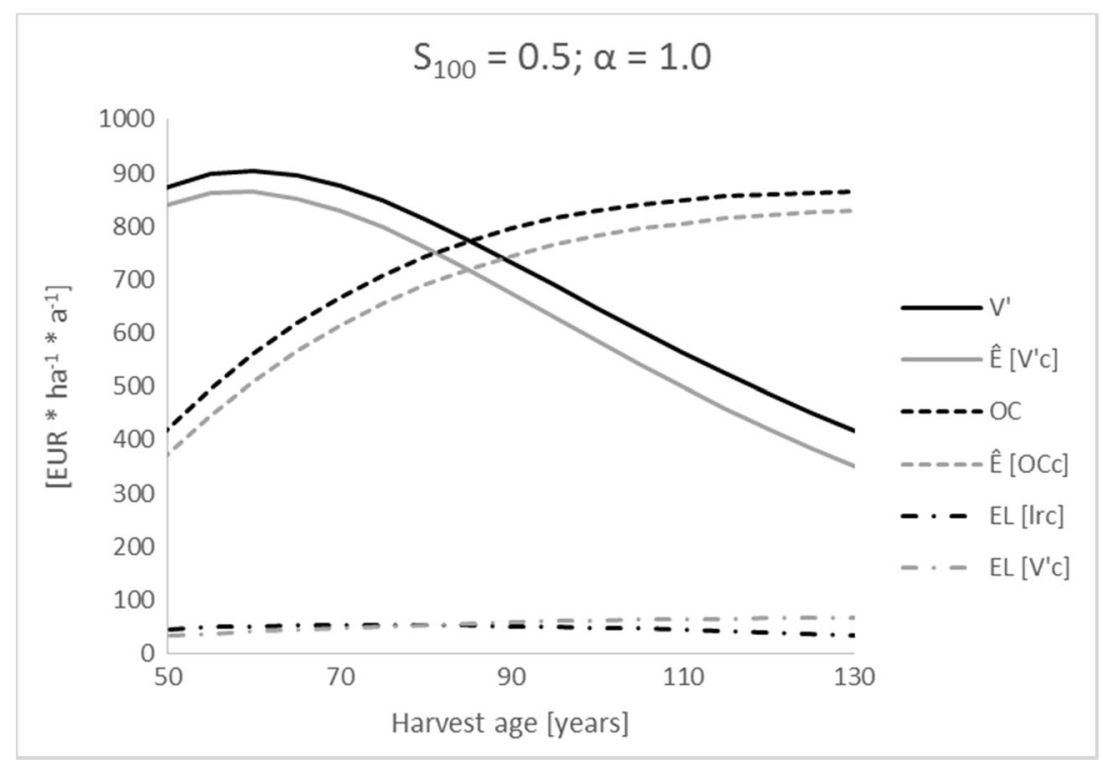

extended FPOT, the harvest of the present stand will be postponed. A parallel change in increment might strengthen or weaken this effect, depending on whether the growing conditions will be worse or better.

\subsubsection{Simulation results}

3.2.2.1 Simulated model components To better understand the calculations leading to the results presented, the following figures show important intermediate steps. Figure 1 shows all annuities included in the calculation of $\hat{E}\left[l r_{c}\right]$ in the case of a set rotation period of 100 years.

Figure 2 shows the corresponding, age-weighted probabilities, while Fig. 3 demonstrates exemplarily an arbitrary, stochastic sequence of 60 stands to justify ageweighting, which is independent from the other results. In it, $l r$ of a soundly harvested forest at rotation age 100 is set to $100 \%$. The $\hat{E}\left[l r_{c}\right]$ reaches nearly $90 \%$ of the risk-free annuity, leading to $E L\left[l r_{\mathrm{c}}\right]$ of about $10 \%$. If a stand is felled due to a calamity, its $l r$ is lower and lasts for a shorter time. Out of the simulated 60 stands, 31 are harvested regularly. Thereby, nearly $59 \%$ of the time line is covered by a sound $l r$, although only about $52 \%$ of all stands grow soundly until the final harvest. An infinite stochastic sequence would lead to the probabilities given in Fig. 2. There, the effect of ageweighting can be seen in the fact that a $S_{100}$ of 0.5 leads to a probability higher than $50 \%$.
Fig. 6 Proceedings of $V^{\prime}$ and $\mathrm{OC}$, their expected values $\hat{E}$ and the resulting EL of high-risk spruce stands $\left(S_{100}=0.5\right)$ under old-age risk $(\alpha=3.0)$. If $E L\left[V_{c}^{\prime}\right]$ are higher than EL $\left[r_{\mathrm{c}}\right]$, optimal harvest is carried out earlier than in a risk-free scenario

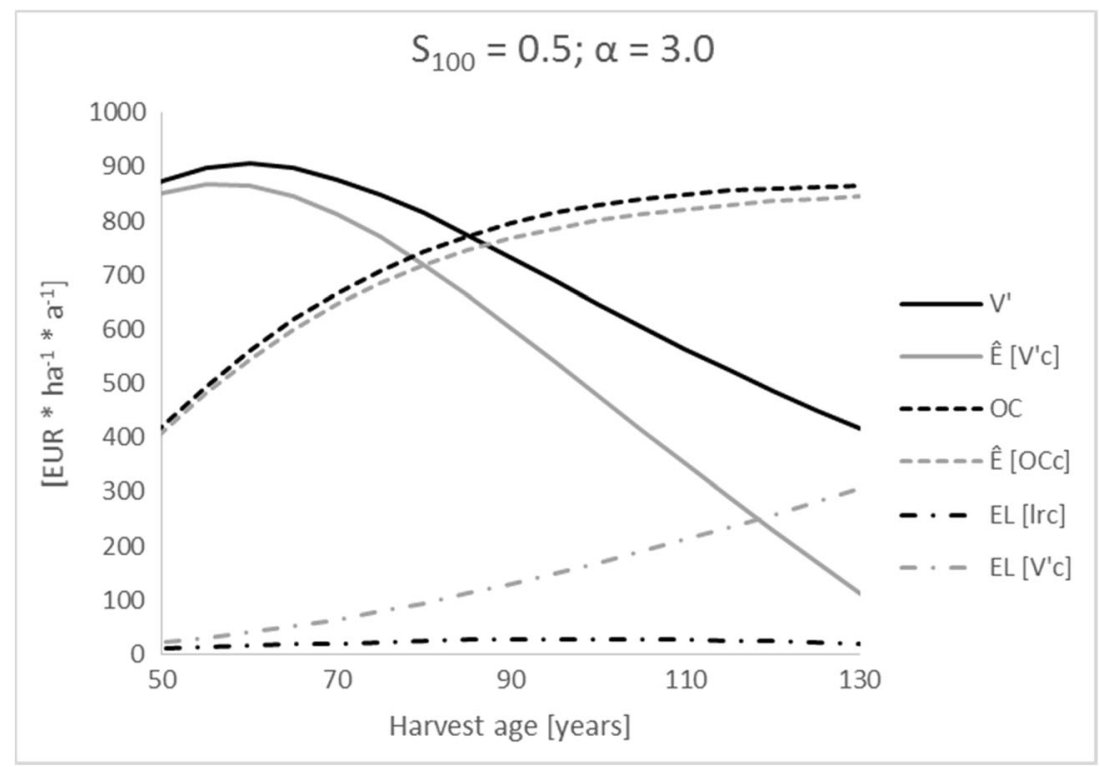


Fig. 7 Proceedings of $V^{\prime}$ and $\mathrm{OC}$, their expected values $\hat{E}$ and the resulting expected losses EL of high-risk spruce stands $\left(S_{100}=\right.$ $0.5)$ under juvenile risk $(\alpha=0.5)$. If EL $\left[l r_{\mathrm{c}}\right]$ are higher than $E L\left[V_{c}^{\prime}\right]$, optimal harvest is carried out later than in a risk-free scenario

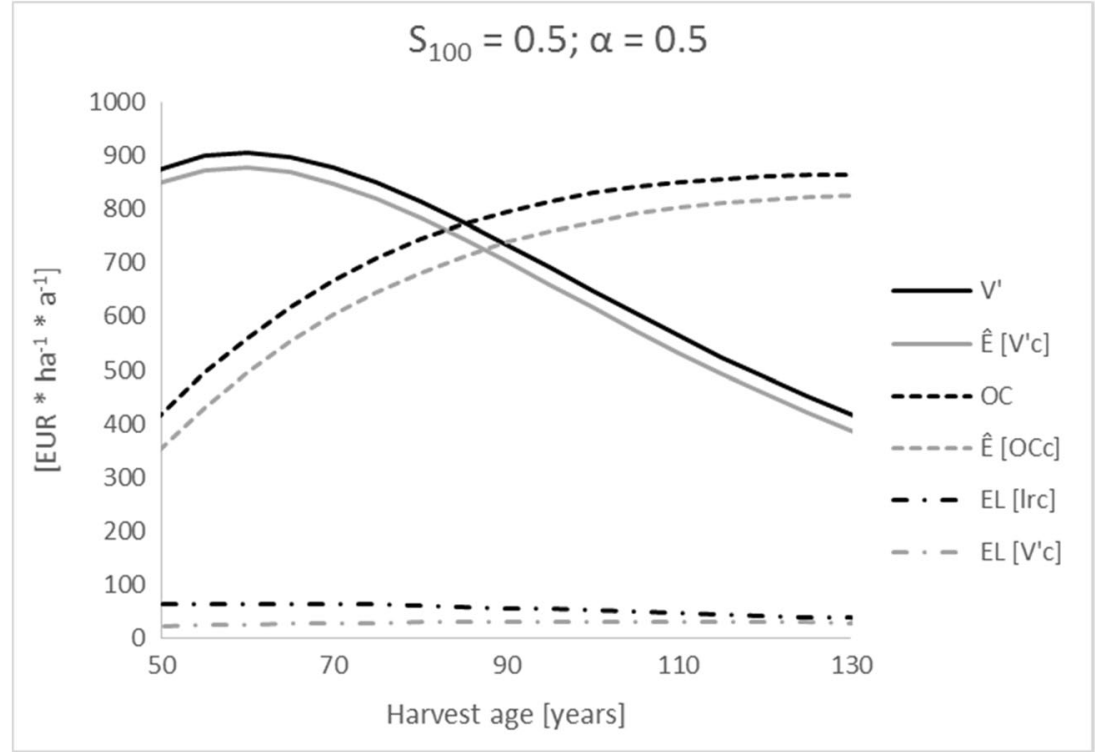

Figure 4 shows the course of the risk-free $l r$, the $\hat{E}\left[l r_{c}\right]$ and $\mathrm{EL}\left[l r_{\mathrm{c}}\right]$ as a function of a preset rotation age. For each rotation, age annuities and probabilities need to be calculated according to Figs. 1 and 2. With a rotation period of 80 years $\hat{E}\left[l r_{c}\right]$ is optimal, while the risk-free $l r$ culminates at age 85 .

3.2.2.2 Simulated effects on optimal harvest age In Figs. 5, 6, and 7 the effects described in Theoretical deductions are visualised. It can be seen that the values of $\hat{E}\left[V_{c}^{\prime}\right]$ and expected OC are, in all cases, lower than in a risk-free scenario. According to the chosen risk-type parameters, old-age risks have a higher influence on harvest age than juvenile risks, while juvenile risks have a higher effect on land rent.

In all cases $E L\left[V_{c}^{\prime}\right]$ generally increases with progressing age. This can be explained through the growing value of a maturing stand. This effect is intensified if the $\alpha$-value is growing, representing a shift towards old-age risks. By this, a high potential loss amount is combined with a high probability.

3.2.2.3 Influence of risk-type and risk-level With $l r$ being a measure of profitability, EL $\left[l r_{\mathrm{c}}\right]$ indicates the severity of a risk. Figure 8 shows the effects on $l r$ of altering risk-levels and types. Unsurprisingly, EL $\left[l r_{\mathrm{c}}\right]$ continually rise with a decreasing $S_{100}$. However, the influence of risk-type on EL $\left[l r_{\mathrm{c}}\right]$ is striking. Juvenile risks make a tree species much less attractive than old-age risks. Here, it comes into effect that, if a stand is damaged at a young age, it has not produced any revenue but only costs. In contrast, an old stand has regularly produced income through thinnings and the damaged wood is still sellable.
Fig. 8 Courses of EL in terms of land rent for spruce stands. Different risk-types are shown in function of risk-level. The EL are calculated, having set the rotation period to the maximum risk-free land rent ( 85 years, black line).

The risk-adapted EL (gray line) are calculated having shifted the rotation age to the maximum land rent under risk

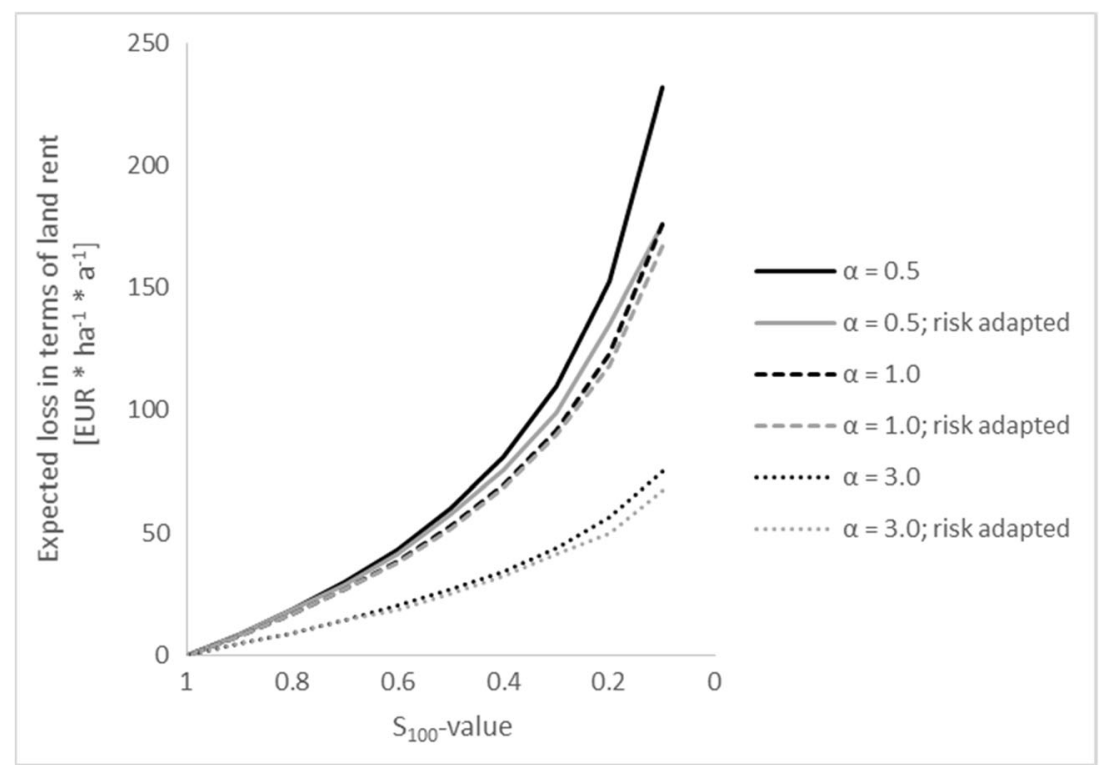


Figure 8 can also be understood as a tool to deduce the maximum price of measures of risk-lowering by either influencing $S_{100}$ or $\alpha$. A measure of risk-handling should not be more expensive than the expected loss. A good example is the tree species change.

Beech has a much lower risk-exposure than spruce and could be seen as a measure of risk-reduction. Yet, according to the simulation, $l r$ of spruce is about EUR 270/ha with EL $\left[l r_{\mathrm{c}}\right]$ of about EUR 30/ha. In contrast, the same model leads to a $l r$ for beech of about EUR 70/ha, marginally influenced by risk. The decision to avoid EL of EUR 30/year by introducing a species with a EUR 200 lower annuity is hardly justified on economic grounds. The shown calculation can also be applied to search for the risk-level at which a change makes sense. Here, EUR 200/ha for EL $\left[r_{\mathrm{c}}\right]$ of spruce arise, when $S_{100}$ approaches zero, meaning that a stand dies back before the age of 100 .

\section{Discussion}

\subsection{Meaning of EL for management decisions}

This study has shown how the concept of EL can be applied in forestry, and that is has a significance to management decisions concerning risk. The meaning is twofold. By knowing $\mathrm{EL}\left[l r_{\mathrm{c}}\right]$ the severity of the risk and the profitability of a species can be determined, which is important for species choice. In combination with the knowledge of $E L\left[V_{c}^{\prime}\right]$ the marginal principle of the FPOT can be applied.

The proposed choice of action regarding harvest age can be summed up by the rule: Avoid risky phases! A rule that might already intuitively be followed, and which has been formulated by Schelhaas (2008). Concerning the final harvest, he concludes that it should be earlier. Our study shows that this is true only when old age risks are predominant, as seems to be the case in the study of Schelhaas. The conclusion to either postpone or forward the final harvest has already been drawn by others. Staupendahl and Möhring (2011) explained the influence of juvenile and old age risks to the optimal rotation period. Loisel (2011) showed how the optimal harvest age can be higher or lower under risk depending on the thinning regime.

Despite these advantages of the risk-extended FPOT, the expected value is not the only crucial parameter to cope with risks. Small forest enterprises might not be harmed by a calamity for a long time, and then completely. In this case, it might rather be opportune to transfer risk to an insurance company (Holthausen et al. 2004). But also, the preferred risk-handling needs to be in accordance with the decision maker's risk-attitude. As this concept also values the fluctuations of income, it might influence the decision essentially. In this study, risk-neutrality has been assumed. The reason for that is the identity of the expected value and the decision value. Assuming a non-risk-neutral decision maker would require the calculation of a safety equivalent, which would go beyond the scope of this study. Recent studies conclude that decision makers in private forestry are rather risk-averse (Brunette et al. 2014; Mußhoff and Maart-Noelck 2014; Sauter et al. 2016), while others conclude that forest owners are predominately risk-loving or risk-neutral (Andersson and Gong 2010). To cover these findings it would be interesting to include risk attitude in the FPOT.

Another way to reduce the result-variance is to renounce a part of the income by mixing the tree species with a less profitable species that has negative correlated risks. To find the right species-mixture, a portfolio selection, such as presented by Knoke (2008), might be the right way. However, without the knowledge of the decision maker's risk-attitude, it is not possible to find the right balance between the accepted loss and the gain in income stability.

\subsection{Magnitude of EL put in perspective}

In spite of the high risk (risk-level $S_{100}=0.5$ ), which nearly doubles the probability of a die-back by age 100 as compared to the risk described in Staupendahl and Zucchini (2011), the level of the expected loss per hectare and year EL $\left[l r_{\mathrm{c}}\right]$ appears quite small, which is also an important result. For the current $E L\left[V_{c}^{\prime}\right]$ confirmation can be found in Holecy and Hanewinkel (2006). They calculated net insurance premiums for sprucedominated forests in southwestern Germany. As the present state is insured, the net insurance premium equals $E L\left[V_{c}^{\prime}\right]$. With values between EUR 0 at age zero and EUR 160 at age 100 their study supports the values presented in Fig. 4.

Reasons for the relative small impact might come from the assumption that, after a calamity, all wood can be sold, ignoring the share of unsaleable broken wood. Yet, this share can be substantial. Costa et al. (2009) presume that $15 \%$ to $50 \%$ of wind-thrown wood of Maritime pine (Pinus pinaster Arr.) in southwestern France cannot be sold. The financial damage would also be higher if a calamity is market-relevant. In Sweden, prices for Norway spruce and Scots pine (Pinus sylvestris L.) dropped to $63 \%$ and $86 \%$ of the before-storm value after storm Gudrun in 2005 (Gardiner et al. 2010). Furthermore, only direct costs of the forest owner were taken into consideration, yet ecosystem services might also be affected. Losses might occur due to soil erosion, lower carbon storage, floods, lower groundwater replenishment, etc. The presented scheme can only include these costs if the forester is financially accountable and the losses are quantified.

Another reason might be that juvenile risks are not well presented in the existing survival functions, while they are crucial according to Fig. 8. As described earlier, most survival 
functions have at least a tendency to old-age risks. It might be crucial that the newer survival functions are based on the German forest-damage survey (Griess et al. 2012; Neuner et al. 2015; Staupendahl and Zucchini 2011), which focusses on the dominating trees and does not include young stands before they are well established (Engels et al. 2013). Yet, it is questionable whether this empirical data from the past is an appropriate source for long-term decisions under a changing climate. This applies foremost to species choice. Climate change will presumably increase EL not only by lowering $S_{100}$ by more frequent events (Seidl et al. 2014), but also by shifting the damaging agents and therefore the $\alpha$-value. If the climate becomes warmer and drier, droughts and forest firesthe agents with highest impact on price changes (Table 2) are more likely to happen (Seidl et al. 2017). Additionally, the $\alpha$-value might get smaller, as young stands lose the advantage they have in a storm-dominated environments. This leads to a lower profitability, either through higher damages or higher costs for preventing measures like firebreaks or pest control. To quantify future EL it would be necessary to develop survival functions on the basis of climate projections. But as the "future climate could follow many different scenarios" (IPCC 2013), forest managers will face uncertainty. Being exposed to uncertainty, forest managers can use the given scheme to provide case studies with varying risk levels, risk types and damage composition. The economic insight gained can then be used for management decisions.

But the chosen form of the function might also influence the result. The survival function $S$ in its presented form cannot describe two phases with a high frequency of destructive events. As juvenile risks seem to have a high economic impact, it would be a valuable task to develop appropriate functions. Despite these explaining arguments, it is also possible that a French proverb is proven correct: A falling tree is louder than a growing forest.

\section{Conclusion}

We conclude that the concept of EL is an appropriate concept for risk-dependent management decisions in forestry, although it does not include all risk aspects. Yet, it can help to objectivise risk handling. The advantage of the shown calculation scheme is its simplicity. The whole calculation can be done at once in just one spreadsheet calculation. It might also be applied to other kinds of risk than natural disturbances, if there is evidence about the probability and the loss amount in the case of realisation.

Acknowledgements The authors would like to thank Philipp Sauter for his excellent cooperation during the online survey. This study was conducted as part of the joint research project "RiskMan", funded by the
Waldklimafonds based on a decision of the German Bundestag (Förderkennzeichen: 28WB401503).

\section{References}

Abdellaoui M, Driouchi A, L'Haridon O (2011) Risk aversion elicitation: reconciling tractability and bias minimization. Theory 71(1):63-80. https://doi.org/10.1007/s11238-009-9192-9

Andersson M, Gong P (2010) Risk preferences, risk perceptions and timber harvest decisions - an empirical study of nonindustrial private forest owners in northern Sweden. For Policy Econ 12(5):330 339. https://doi.org/10.1016/j.forpol.2010.02.002

Brunette M, Foncel J, Kéré EN (2014) Attitude towards risk and production decision: an empirical analysis on French private forest owners. Serie Etudes et Documents du CERDI 19(10):3-18

Brunette M, Holecy J, Sedliak M, Tucek J, Hanewinkel M (2015) An actuarial model of forest insurance against multiple natural hazards in fir (Abies alba Mill.) stands in Slovakia. For Policy Econ (55):4657. https://doi.org/10.1016/j.forpol.2015.03.001

Burkhardt T, Möhring B, Gerst J (2014) Modeling natural risks in forest decision models by means of survival functions. In: Kant S, Alavalapati, Janakai RR (eds) Handbook of Forest resource economics, 1st edn. Routledge, New York, pp 322-340

Campalongo F, Jönsson H, Schoutens W (2013) Quantitative assessment of securitisation deals. Springer, Heidelberg

Chang SJ, Deegen P (2011) Pressler's indicator rate formula as a guide for forest management. J For Econ 17(3):258-266. https://doi.org/10. 1016/j.jfe.2011.04.002

Costa S, Lecocq M, Drouineau S, Peyron J (2009) Évaluation du préjudice monétaire subi par les propriétaires forestiers suite à la tempête Klaus : le cas des dégâts subis par le Pin maritime. Rev For Fr 61(1):49-66

Engels F, Block J, Wunn U (2013) Methodenbeschreibung Terrestrische Waldzustandserhebung (WZE) in Rheinland-Pfalz. http://www. wald-rlp.de/fileadmin/website/fawfseiten/fawf/FUM/ umweltmonitoring/methoden.pdf. Accessed 7 April 2017

Faustmann M (1849) Berechnung des Werthes, welchen Waldboden, sowie noch nicht haubare Holzbestände für die Waldwirthschaft besitzen. Allg Forst- Jagdztg 21(12):441-455

Gardiner B, Blennow K, Carnus J, Fleischer P, Ingemarson F, Landmann G, Lindner M, Marzano M, Nicoll B, Orazio C, Peyron J, Reviron M, Schelhaas M, Schuck A, Spielmann M, Usbeck T (2010) Destructive storms in European forests: past and forthcoming impacts: final report to European Commission - DG Environment

Griess VC, Knoke T (2013) Bioeconomic modeling of mixed Norway spruce-European beech stands: economic consequences of considering ecological effects. Eur J For Res 132(3):511-522. https://doi. org/10.1007/s10342-013-0692-3

Griess VC, Acevedo R, Härtl F, Staupendahl K, Knoke T (2012) Does mixing tree species enhance stand resistance against natural hazards? A case study for spruce. For Ecol Manage (267):284-296. https://doi.org/10.1016/j.foreco.2011.11.035

Haight RG, Smith WD, Straka TJ (1995) Hurricanes and the economics of loblolly pine plantations. For Sci 41(4):675-688

Hanewinkel M, Hummel S, Albrecht A (2011) Assessing natural hazards in forestry for risk management: a review. Eur J For Res 130(3): 329-351. https://doi.org/10.1007/s10342-010-0392-1

Holecy J, Hanewinkel M (2006) A forest management risk insurance model and its application to coniferous stands in southwest Germany. For Policy Econ 8(2):161-174. https://doi.org/10.1016/j. forpol.2004.05.009 
Holthausen N, Hanewinkel M, Holecy J (2004) Risikomanagement in der Forstwirtschaft am Beispiel des Sturmrisikos. Forstarchiv 75:149157

IPCC (2013) Climate change 2013: the physical science basis. Contribution of working group I to the fifth assessment report of the intergovernmental panel on climate change. Cambrige University Press, Cambridge

Johansson P, Löfgren K (1985) The economics of forestry and natural resources. Blackwell, Oxford

Klemperer WD (1996) Forest resource economics and finance. McGrawHill, New York

Knoke T (2008) Mixed forests and finance - methodological approaches. Ecol Econ 65(3):590-601. https://doi.org/10.1016/j.ecolecon.2007. 08.009

Kölling C, Mette T, Knoke T (2016) Waldertrag und Anbaurisiko in einer unsicheren Klimazukunft. Schweiz Z Forstwes 167(1):29-38. https://doi.org/10.3188/szf.2016.0029

Kouba J (2002) Das Leben des Waldes und seine Lebensunsicherheit. Forstwiss Centbl 121:211-228

Loisel P (2011) Faustmann rotation and population dynamics in the presence of a risk of destructive events. J For Econ 17(3):235-247. https://doi.org/10.1016/j.jfe.2011.02.001

Möhring B (2009) Wie gelingt der Brückenschlag zwischen Theorie und Praxis bei den ökonomischen Hiebsreifekriterien? Forstarchiv 80: $109-118$

Mußhoff O, Maart-Noelck SC (2014) An experimental analysis of the behavior of forestry decision-makers - the example of timing in sales decisions. For Policy Econ (41):31-39. https://doi.org/10. 1016/j.forpol.2013.12.006

Nagel J (2010) Der WaldPlaner. Nordwestdeutsche Forstliche Versuchsanstalt, Göttingen

Neuner S, Albrecht A, Cullmann D, Engels F, Griess VC, Hahn WA, Hanewinkel M, Härtl F, Kölling C, Staupendahl K, Knoke T (2015) Survival of Norway spruce remains higher in mixed stands under a dryer and warmer climate. Glob Change Biol 21(2):935946. https://doi.org/10.1111/gcb.12751
Preßler M (1860) Zur Verständigung über den Reinertragswaldbau und sein Betriebsideal 3. Allg Forst Jagdztg 36:261-269

Sauter PA, Möllmann TB, Anastassiadis F, Mußhoff O, Möhring B (2016) To insure or not to insure? Analysis of foresters' willingness-to-pay for fire and storm insurance. For Policy Econ (73):78-89. https://doi.org/10.1016/j.forpol.2016.08.005

Schelhaas M (2008) Impacts of natural disturbances on the development of European forest resources: application of model approaches from tree and stand levels to large-scale scenarios. Dissertationes Forestales, vol 56. Faculty of Forestry of the University of Joensuu, Joensuu

Schelhaas M, Nabuurs G, Hengeveld G, Reyer C, Hanewinkel M, Zimmermann NE, Cullmann D (2015) Alternative forest management strategies to account for climate change-induced productivity and species suitability changes in Europe. Reg Environ Chang 15(8):1581-1594. https://doi.org/10.1007/s10113-015-0788-Z

Seidl R, Schelhaas M, Rammer W, Verkerk PJ (2014) Increasing forest disturbances in Europe and their impact on carbon storage. Nat Clim Chang 4(9):806-810. https://doi.org/10.1038/nclimate2318

Seidl R, Thom D, Kautz M, Martin-Benito D, Peltoniemi M, Vacchiano G, Wild J, Ascoli D, Petr M, Honkaniemi J, Lexer MJ, Trotsiuk V, Mairota P, Svoboda M, Fabrika M, Nagel TA, Reyer, Christopher PO (2017) Forest disturbances under climate change. Nat Clim Chang 7(6):395-402. https://doi.org/10.1038/nclimate3303

Staupendahl K (2011) Modellierung der Überlebenswahrscheinlichkeiten von Waldbeständen mithilfe der neu parametrisierten WeibullFunktion. Forstarchiv 82(1):10-19

Staupendahl K, Möhring B (2011) Integrating natural risks into silvicultural decision models: a survival function approach. For Policy Econ 13(6):496-502. https://doi.org/10.1016/j.forpol.2011.05.007

Staupendahl K, Zucchini W (2011) Schätzung von Überlebensfunktionen der Hauptbaumarten auf der Basis von Zeitreihen der RheinlandPfälzischen Waldzustandserhebung. Allg Forst Jagdztg 182(7/8): 129-145 